\title{
TRAJEKTORI STUDI ADMINISTRASI PUBLIK
}

\author{
M. Rizki Pratama \\ Fakultas Ilmu Administrasi, Universitas Brawijaya \\ email: pratamarizkim@ub.ac.id
}

\begin{abstract}
This study explains the trajectory of public administration (PA) time to time. Public Administration has experienced many significant developments since the writing of the study of administration by Wilson in 1887. Starting from the identity crisis, the re-recognition of the study of public administration to the emergence of new public administration was increasingly growing when the new public management was introduced. The journey of PA has found its own way as a science that must be interpreted as a science that cannot stand alone but has its own character, especially how to look at the affairs of the public sector or everything related to the public in general. PA is not a science that has no clear boundaries or has a high degree of blurring. As long as the criticism shows the dynamics that actually employs PA studies instead of shutting down PA studies themselves. PA experiences patterns from the past to the future can be conceptualized into an PA trajectory. This trajectory certainly cannot be considered full and absolute effect, of course there are several loopholes and really in need to be criticized. The development and change of the PA study has reached an encouraging stage when in the current era the PA study has been considered as a tool to achieve a better society and country life, if the government is considered bad government then the PA is used as a guide to reform as well as being used to review current government performance through various kinds of PA theories that already exist.
\end{abstract}

Keyword: public administration; trajectory; reform.

\begin{abstract}
ABSTRAK
Studi ini menjelaskan trajektori (lintasan) studi administrasi publik (AP) dari masa ke masa. Studi Administrasi Publik telah mengalami banyak perkembangan berarti sejak dituliskannya studi administrasi oleh Wilson pada tahun 1887. Mulai dari krisis identitas, pengakuan kembali studi administrasi publik hingga munculnya administrasi publik baru yang semakin pesat ketika new public management mulai diperkenalkan. Perjalanan studi AP telah menemukan jalannya sendiri sebagai ilmu yang harus dimaknai sebagai ilmu yang tidak dapat berdiri sendiri akan tetapi memiliki karakter sendiri dan menjadi ciri khasnya terutama bagaimana memandang urusan sektor publik atau segala sesuatu yang berhubungan dengan publik secara umum. Ilmu AP bukanlah ilmu yang tidak jelas batasannya atau memiliki kadar kekaburan yang tinggi. Sepanjang kritik yang ada menunjukkan dinamika yang justru memperkarya studi AP bukan malah mematikan studi $A P$ sendiri. Pola perjalanan AP dari masa lalu hingga masa depan dapat dikonsepkan menjadi sebuah trajektori AP. Trajektori ini tentu tidak dapat dianggap penuh dan berlaku mutlak tentu masih banyak kelemahan serta sangat perlu untuk dikritisi. Perkembangan dan perubahan studi AP telah mencapai tahap yang menggembirakan ketika pada era saat ini studi AP telah dianggap sebagai alat untuk mencapai kehidupan masyarakat dan Negara yang lebih baik, jika pemerintahan dianggap buruk maka AP dijadikan panduan untuk mereformasi sekaligus digunakan untuk meninjau kondisi pemerintahan saat ini melalui berbagai macam teori AP yang telah ada.
\end{abstract}

Kata Kunci: administrasi publik; trajektori; reformasi. 


\section{PENDAHULUAN}

Pada masa awal studi administrasi publik (AP) telah banyak diulas bahwa titik tumpu studi hanya berkisar pada tata legal formal organisasi pemerintah dengan struktur yang rigid dan hirarkis. Semua hal yang berkaitan dengan pemerintah harus melalui yurisdiksi aturan yang baku sehingga menunjukkan studi AP masih dipandang sebagai kegiatan pemerintah dalam menyelesaikan tugasnya sesuai aturan.

AP adalah sebuah fungsi untuk mengekspersikan nilai dan preferensi dari warga negara, komunitas, dan masyarakat secara keseluruan (Bourgon, 2007). Oleh karena itu AP terus berkembang dan bertumbuh mulai tentang dikotomi administrasi-politik (Wilson, 1887), pemikiran paradigmatik (Henry, 2012), administrasi publik baru (Frederickson, 1980). Lalu bergerak cepat ke arah science yang praktikal untuk melakukan reform lewat New Public Management (D. Osborne \& Gaebler, 1993). Bahkan New Public Management (NPM) mampu terdifusi ke hampir seluruh Negara di dunia sebagai paradigma reformasi sektor publik meskipun dengan berbagai kritik (Drechsler, 2005; Nemec, 2014). Lahir dari kritik terhadap NPM kemudian muncul New Public Service (Denhardt \& Denhardt, 2007). Era pasca NPM juga menunjukkan berbagai variasi pemikiran lainnya seperti Sound of Governance (Farazmand, 2004), Public Value Management (Stoker, 2006), New Governance (Rhodes, 1996), New Public Governance (S. P. Osborne, 2010), Neo Weberian State (Drechsler \& Kattel, 2008; Pollit \& Bouckaert, 2011, 2017), Collaborative Governance (Emerson, Nabatchi, \& Balogh, 2011) hingga Smart Governance (Meijer \& Bolivar, 2016; Tomor, Meijer, Michels, \& Geertman, 2019).

Dinamisnya pemikiran baik perkembangan dan kritik menujukkan bahwa AP adalah sebuah studi dalam masa transisi dan belum stabil (Vigoda, 2002). AP memiliki paradigma yang berbeda dari ilmu tradisional, AP adalah ilmu postnormal (Riccucci, 2010). Perkembangan objek studi juga menunjukkan bahwa AP hidup pada ruang-ruang publik (Bozeman, 2007), derajat organisasi publik yang ternyata tidak mudah didefinisikan sebagai publicness (Pesch, 2008). Usaha untuk melakukan de-westernization dalam studi AP juga terus menghangat seperti semakin urgennya studi komparasi administrasi publik untuk pandangan non-american dan hadirnya islamic public administration (Drechsler, 2015, 2017; Raadschelders \& Lee, 2011).

Semakin dinamisnya perdebatan mendorong studi AP untuk terus berkembang. Perlu pandangan positif untuk membuat kesimpulan atas perdebatan tersebut sehingga sebenarnya berbagai macam persoalan yang ada merupakan bagian dari perubahan dan perkembangan keilmuan yang masih tergolong muda untuk berkembang menjadi lebih matang di masa mendatang. Oleh karena itu sangat perlu untuk memberikan gambaran masa depan melalui sebuah skenario tentang perjalanan studi administrasi publik selanjutnya. Konsep prediksi disini akan menggunakan sebuah trajektori yang bukan sekadar sebuah trend yang akan sangat cepat berubah akan tetapi lebih persisten dan konsisten (Pollit \& Bouckaert, 2011). Tulisan ini memberikan sebuah gambaran bagaimana prediksi ke arah mana studi studi ilmu administrasi publik akan bergerak ataupun sebuah trajektori pada trek-trek keilmuan berdasarkan perkembangan dan perubahan studi pada masa lalu dan masa sekarang.

\section{TINJAUAN PUSTAKA}

Pada dasarnya konsep trajektori telah digunakan dalam berbagai studi akan tetapi dalam ilmu-ilmu sosial lebih banyak digunakan dalam studi politik dan hubungan internasional seperti perdebatan teori dan perkembangan studi hubungan internasional baik sejarah maupun konsepsi masa depan (Mantra, 2015; Susanto, 2012). Dalam pembahasan trajektori tersebut muncul tiga kata kunci yaitu sejarah, masa kini dan masa 
depan. Konsep trajektori setidaknya harus memuat tiga elemen penting tersebut tentang bagaimana sejarah perkembangan suatu studi, kondisi masa kini terutama dinamika dan perdebatannya lalu kemudian bagaimana prediksi apa yang terjadi di depan tentang studi tersebut.

Pada studi administrasi publik konsep trajektori tidak jauh berbeda. Sebuah trajektori dimulai dari titik awal (an alpha) ke situasi tertentu yang diinginkan di masa mendatang (an omega) (Pollit \& Bouckaert, 2011). Sehingga pada dasarnya untuk menentukan sebuah trajektor diperlukan analisis tentang titik awal sebagai kondisi awal yang digunakan untuk menggambarkan titik akhir di masa depan. Dalam perjalanan dari titik awal ke masa depan tentu diperlukan analisis lain tentang dinamika yang terjadi selam rentang titik awal menuju masa depan. Oleh karena itu jika dikaitkan dengan studi administrasi publik baik titik awal, masa depan dan dinamika diantaranya selalu menggantungkan pada tiga elemen kompleks yaitu pertama, paradigma studi yang seringkali dianggap kurang jelas. Kedua, objek studi yang terlalu luas. Dan Ketiga, konteks studi yang terlalu berpihak ke barat.

\section{METODE}

Penelitian menggunakan studi literatur sebagai metode utama guna memperoleh data tentang trajektori studi administrasi publik. Studi literatur ini berguna untuk mengumpulkan dan mensintesis berbagai literatur sebelumnya dengan cara-cara yang sistematis (Snyder, 2019). Untuk menentukan literatur yang dianalisis diperlukan beberapa tahap yaitu memformulasikan, masalah, mencari literatur, membuat kategori literatur, memeriksa kualitas, mengekstrasi informasi penting serta menganalisis dan mensintesis data (Templier \& Pare, 2016). Oleh karena itu pasca menentukan tujuan penelitian diperlukan prosedur untuk menginklusi kriteria literatur yang digunakan. Oleh karena itu peneliti menggunakan tiga basis untuk melakukan screening literatur yaitu: Pertama, berbasis paradigma: literatur yang digunakan memiliki penjelasan tentang sejarah studi administrasi publik dan paradigma dari klasik hingga modern. Literatur yang dikumpulkan seperti: pemikiran paradigmatik (Henry, 2012), administrasi publik baru (Frederickson, 1980), New Public Management New Public Service (Denhardt \& Denhardt, 2007). Era pasca NPM juga menunjukkan berbagai variasi pemikiran lainnya seperti Sound of Governance (Farazmand, 2004), Public Value Management (Stoker, 2006), New Governance (Rhodes, 1996), New Public Governance (S. P. Osborne, 2010), Neo Weberian State (Drechsler \& Kattel, 2008; Pollit \& Bouckaert, 2011, 2017), dst. Kedua, berbasis objek: literatur yang digunakan memiliki penjelasan tentang fokus studi adminisrasi publik. Literatur yang dikumpulkan seperti: ilmu postnormal (Riccucci, 2010), ruang-ruang publik (Bozeman, 2007), publicness (Pesch, 2008), dst. Ketiga, berbasis konteks: literatur yang digunakan memiliki penjelasan tentang perkembangan studi administrasi publik dari berbagai konteks baik pendekatan barat dan timur. Literatur yang dikumpulkan seperti Public Managemet Reform di Eropa (Pollit \& Bouckaert, 2011, 2017), islamic public administration (Drechsler, 2015, 2017).

Pasca literatur dikumpulkan peneliti pada akhirnya dapat mengklasifikasi analisis menjadi empat bagian utama yaitu: Pertama, tentang status quo studi administrasi publik yang tetap mewarnai hingga hari ini yaitu administrasi publik klasik. Kedua, tentang refokus studi administrasi publik yang menuju ke fokus politik dan manajemen. Ketiga, tentang arah studi administrasi publik dari tiga aliran besar. Berdasarkan ketiga analisis tersebut kemudian dianalisis kembali untuk menemukan analisis yang Keempat yaitu tentang administrasi publik untuk reformasi yang memberikan solusi permasalahan sektor publik di era saat ini. 


\section{HASIL DAN PEMBAHASAN}

\section{Status Quo Administrasi Publik Klasik}

Kondisi awal atau dalam konsep Pollit dan Bouckaert disebut dengan initial situation tentang studi administrasi publik (AP) mulai terjadi pada saat kelahiran studi yang didasarkan pada tulisan Woodrow Wilson dengan judul The Study of Administration (1887). Tulisan Wilson menjadikan AP menjalani debut dalam dunia akademis sehingga mulai banyak diperbincangkan pada saat itu. Dua kalimat kunci dari Wilson menjadi bangunan teori utama bagi perkembangan AP selanjutnya yaitu administrasi bebas dari politik dan jauh lebih sulit untuk menjalankan aturan daripada membuatnya. Konsekuensi dari dua pendapat itu dalam dunia pemerintahan maka aparatur harus profesional dan tunduk pada aturan yang dibentuk oleh para politisi. Wilson juga memberikan deskripsi lebih pada bagian bahwa administrasi adalah apolitis dan menjadi alasan mengapa ilmu AP lahir. Seperti dikutip dalam jurnal aslinya Politic and administration could be distinguished, he argued as the expression of the will of the state and the execution of that will (Wilson, 1887).

Politik dan administrasi dapat dipisahkan sebagai ekspresi keinginan dari Negara dan eksekusi dari keinginan tersebut. Secara garis besar pendapat Wilson menyatakan bahwa ilmu administrasi harus memperkuat jalan pemerintah, membuat urusannya menjadi kurang seperti urusan bisnis, memperkuat dan memurnikan tanggung jawabnya.

Pasca tulisan Wilson yang mulai tersebar luas maka setelah itu terjadilah berbagai pedebatan sengit ketika itu bahkan hingga muncul pendapat bahwa AP bukanlah sebuah bidang studi sehingga tidak perlu untuk didirikan faculty khusus untuk membahasnya. Dalam perjalanannya AP mengalami nasib pasang surut mulai pada awalnya berbeda dengan politik, kemudian masuk ke dalam studi politik, kembali keluar dari politik dan menjadi studi administrasi dan yang terakhir mulai menemukan jatidirinya menjadi science yang berdiri sendiri yaitu sebagai AP. Berbagai perdebatan seru tersbeut kemudian dirangkum oleh seorang ilmuwan AP melalui pembagian perkembangan keilmuan AP melalui paradigma, yaitu Henry (2012) yang membagi AP menjadi lima paradigma yaitu pertama, paradigma dikotomi politik administrasi (1900-1926). Kedua, Prinsip-prinsip administrasi (1927-1937). Ketiga, Administrasi negara sebagai ilmu politik (1950-1970). Keempat, Administrasi negara sebagai ilmu administrasi (1956-1970). Kelima, administrasi negara sebagai administrasi negara (1970). Pada setiap paradigma selalu muncul perubahan dan perkembangan hingga pada perkembangan terakhir menimbulkan identitas AP sendiri yaitu harus dipahami sebagai AP.

Masa pencarian paradigma ini dapat juga disebut dengan masa klasik AP yang kini dapat merupakan status quo dari studi AP sendiri. Secara kontekstual dapat dilihat bahwa hampir seluruh Negara di dunia menggunakan konsep AP klasik dalam mengembangkan manajemen pemerintahannya termasuk aplikasi birokasi ala Weber yang hirarkhis dan rasional. Paradigma ortodoks mewakili dari dominasi manajemen sains yang sangat ketat memastikan efisiensi, efeftivitas serta prinsip ekonomi dalam kegiatan pemerintah (Riccuci, 2010). Masa ini menjadi titik awal dari sebuah trajektori AP.

AP klasik ini juga ditambahkan dengan berbagai pendapat untuk menemukan paradigma dan teori baru, seperti penjelasan Frederickson dalam tulisannya Toward $A$ New Public Administration. Frederickson (1980) sendiri mengungkapkan the four suggested procesess: the distributive process, the inegrative process, the boundaryexchange process and the socio-emotional processes. Bahwa di masa mendatang 
menurut Frederickson bangunan teori AP akan dimulai dari proses distribusi, integrasi, pertukaran antar batas serta memiliki dampak sosial-ekonomik. Kemudian juga diperkuat bahwa studi AP mempunya tiga titik tumpu analisis yaitu hukum, politik dan manajemen (Rosenbloom, 2013).

Tiga titik analisis merupakan pendapat yang paling awet tentang memahami studi AP daripada pendapat pakar yang lain. Ketiga perspektif tersebut dianggap sukses karena sederhana sedangkan pandangan lain kekurangan penjelasan, baik struktrual, fungsional atau institusional dalam pemerintah atau governance. Kedua pendapat pakar besar tersebut memberikan pijkan kuat pada administrasi publik klasik terutama bagaimana mereka telah memberikan identitas keilmuan, meskipun banyak pakar yang lain dalam masa klasik ini akan tetapi pendapat keduanya masih tetap berlaku hingga sekarang sehingga dapat juga disebut sebagai status quo studi AP.

\section{Refokus Administrasi Publik: Politik Dan Manajemen}

Salah satu pergeseran penting yang terjadi pada abad 21 pada studi administrasi publik (AP) adalah terjadi pergeseran dari government ke governance. Jika pada awalnya pemerintah mendominasi maka hari ini dominasi tersebut tidak akan pernah terjadi lagi, sebagian besar kekuasaan sudah terdistribusikan kepada lembaga dan aktor di luar pemerintahan sehingga akan menghasilkan kebijakan yang lebih komprehensif. Semakin banyak pihak yang terlibat sehingga kini tidak mungkin hanya menggunakan pendekatan ekonomi manajemen yang efektif dan efisien akan tetapi juga harus tunduk pada kepentingan dan kebutuhan publik. Hal semacam ini tentu tidak diketemukan pada masa perkembangan dan perubahan studi AP pada masa lalu yang hanya fokus pada salah satu pendekatan, singkatnya pada era AP saat ini terjadi pertemuan antara politik dan manajemen. Pertemuan ini memang tidak mengejutkan karena sudah pernah diprediksi oleh para pakar sebelumnya.

Argumen Dwiyanto (2004) dalam pidato Guru Besarnya: di dalam studi governance, administrasi publik didefiniskan sebagai proses penggunakan kekuasaan administratif, politik dan ekonomi untuk menyelesaikan masalah-masalah publik. Melalui pendekatan tersebut dapat dimaknai bahwa administrasi memiliki kedudukan yang sejajar dengan politik dan ekonomi sehingga ketiganya dapat saling memperkuat dan mendukung analisis masing-masing. Pasca melewati berbagai macam perdebatan maka studi AP bergerak terus menurs untuk menjadi panduan pada setiap bagian organisasi publik, baik pemerintah ataupun masyarakat sendiri. Studi AP lambat laun menyerap hampir seluruh bidang ilmu sosial sehingga studi AP memliki banyak level analisis dan berbagai kepingan studi yang memperkaya pendalamannya, seperti halnya kebijakan publik, manajemen pelayanan publik, manajemen sumber daya manusia, hingga hubungan antar lembaga juga diperbicangkan dalam studi AP. Kini bicara AP selalu tidak dapat berdiri sendiri dan harus mempertimbangkan banyak analisis lain. Hal tersebut juga diperkuat dengan banyaknya studi interdisplin dalam studi administrasi publik (Vigoda, 2002).

Pendapat lain juga menyatakan bahwa manjemen publik tidak dapat berdiri sendiri tanpa berkaitan dengan hubungan yang krusial antara administrasi dan politik, From the outset we have argued that public management cannot be adequately comprehendedwithout reference to the crucial relationships which exist between administrationand politics, and between administrators and politicians. In making this point we arejust one more member of a large chorus (Pollit \& Bouckaert, 2011).

Arah perkembangan dan perubahan AP cenderng menuju arah ekonomi dan politik dan mulai meninggalkan tata legal formal hukum sendiri, ini sangat penting 
sebab AP dipandang akan mencari jalan sendiri untuk memenuhi kepentingan publik bukan hanya statis pada hukum formal semata. Negara tidak lagi pemain tunggal, kini banyak pemain lain dengan berbagai peran oleh karena itu terkadang sulit untuk menentukan permainan apa yang dimainkan dan aturan apa yang diikuti (Stivers, 2001). Dalam konteks Negara maka akan ada kebingungkan aktor manakah yang mendominasi dan aturan apa yang dipergunakan, dinamika tersebut mewarnai perjalanan studi AP yang kini lebih menonjolkan sisi kepentingan publik sendiri daripada dominasi suatu Negara.

Saat ini masa perkembangan AP berubah mengikuti perkembangan zaman, pendapat dari Farazmand (2012): administrasi negara kesejahteraan menjadi negara kesejahteraan korporat yang koersif, dari administrasi urusan publik menjadi administarsi dari "publik", dari administrasi negara ke dominasi negara melalui militer. AP berubah dan bertransformasi terutama dari hanya dari administrasi urusan publik menjadi administrasi yang benar-benar oleh publik, AP berubah dari kontrol militer yang keras ke arah yang mempromosikan kapitalisme dan tahapan pembangunan lanjutannya. Perubahan ini dipandang sebagai subtansi bahwa AP tetap ada bersama Negara untuk berubah mengikuti arah global.

Arus utama yang dapat dijadikan trajektori AP adalah ketika perdebatan pemisahan administrasi dan politik sudah tidak berlaku lagi, AP tidak dianggap hidup diruang hampa sehingga akan selalu dipengaruhi oleh lingkungannya. Arus utama yang mempengaruhi AP adalah politik yang menciptakan keadilan dan manajemen yang berorientasi pada efisiensi dan efektivitas. Dalam dua pengaruh besar ini, tentu tidak akan dapat terelakkan bahwa sejak globalisasi muncul hampir-hampir studi AP selalu terpengaruh, misalkan ketika UNDP merumuskan good governance maka hampir seluruh Negara di dunia mencoba untuk melakukannya sebagai konsepsi pemerintahan yang ideal. Hal ini membuktikan politik dan manajemen yang kini menjadi arus utama fondasi AP. Sebuah momentum ketika pertemuan tersebut merupakan analisis utama AP sehingga segala bentuk perbaikan pemerintahan akan selalu dikatikan dengan dua hal tersebut, jika hendak memperbaiki kondisi pemerintahan maka aspek politik dan manajemen akan menjadi titik tumpu. Hal ini tentu memberikan tempat tersendiri bagi studi AP sebagai tempat awal berangkat untuk melakukan perubahan secara drastis atau reformasi. Pengaruh politik dan manajemen menjadi yang terkuat hingga membuat pergeseran keilmuan dan bahkan banyak pakar yang mensinonimkan AP dengan manajemen publik. Manajemen untuk merujuk pada manajemen sendiri sedangkan publik merujuk pada kepentingan publik, ruang-ruang publik hingga lembaga publik, meskipun hingga saat ini menjadi perdebatan akan tetapi baik AP maupun manajemen publik selalu saja dipertukarkan sebagai konsep yang sama sehingga keduanya dianggap memiliki tempat yang sama untuk melakukan reformasi.

AP sudah dianggap sebagai alat panduan yang komprehensif dalam menangani masalah publik, bukan hanya masalah pemerintah dan Negara.Sudah seharusnya AP memliki jalur sebagai fondasi utama untuk melakukan perbaikan tata kelola kepemerintahan melalui reformasi yang kini tidak hanya mempertimbangkan aspekaspek ekonomi yang efisien dan efektif akan tetapi juga memperhatikan kepentingan publik. Inilah jalur utama studi AP yang tengah berkembang di masa sekarang dan akan terus melalui jalur yang sama di masa mendatang. AP memberikan satu satunya jalan terbaik guna menuju pemerintahan yang lebih baik melalui berbagai model yang akan dibahas selanjutnya. 


\section{Arah Administrasi Publik: Neo Weberian State, New Public Management \& New Public Governance}

Untuk memenuhi kebutuhan perbaikan sistem administrasi publik (AP) maka pada era modern pasca New Public Administration ala Frederickson setidaknya ada tiga arus utama yang dapat dikedepankan sebagai model terbaik bagi sistem AP. Tiga model tersebut merupakan alat untuk me-reform agar governance menjadi lebih baik, disini dapat disebutkan pertama yaitu New Public Management (NPM) sebagai model liberal dalam reform.Kedua, Neo Weberian State (NWS) yang merupakan pengembangan dari model birokrasi Weber untuk disesuaikan dengan masa sekarang. Ketiga adalah New Public Governance yang menjadi pemikiran termutakhir dari studi AP.

Pengertian dari NPM memang dapat dikatakan sebagai model yang paling ekonomis dalam artian benar-benar membebaskan organisasi publik untuk mencari profit sehingga kinerja organisasi menjadi efisien karena memang berbasis lingkungan bisnis dan pasar. NPM :To make government more efficient and 'consumer-responsive'by injecting business like methods (D. Osborne \& Gaebler, 1993). Sepakat dengan pendapat tersebut bahwa tujuan dari NPM adalah untuk membuat pemerintah lebih efisien dan responsif pada konsumen dengan menyuntikkan metode bisnis. Hal ini sedikit berbeda dengan model NWS yang berfokus pada sumber daya manusia untuk menjadi lebih professional (Pollit \& Bouckaert, 2011, 2017). NWS sendiri memiliki tujuan untuk merubah aparat tradisional menjadi lebih profesional. Prinsip-prinsip bisnis hanya akan menjadi tambahan, sedangkan negara tetap menjadi aktor yang sebenarnya dengan memiliki aturan, metode dan budaya sendiri. Kemudian dengan model NPG yang dipopulerkan oleh Stephen Osborne melalui buku yang dieditnya The New Public Governance ?Emerging Perspective On The Theory And Practice Of Public Governance, memiliki titik tumpu bahwa kebijakan harus berbasis jaringan dan multistakeholder. NPG: To make government more effective and legitimate by including a wider range of socialactors in both policymaking and implementation. Some varieties of governance explicitly rest on a 'network approach', and most of them emphasize 'horizontality' over vertical controls (S. P. Osborne, 2010). Lebih lengkap lagi NPG membuat pemerintah lebih efektif dan memiliki legitimasi dengan melibatkan banyak aktor baik dalam pembuatan kebijakan dan implementasi. Inti dari model ini adalah pendekatan jaringan dan menekankan kontrol horizontal daripada vertikal.

Semua model diatas adalah relatif dan tidak mungkin menjadi sebuah idealisme $100 \%$ bisa saja saling bercampur dan bahkan juga akan ada banyak Negara yang hanya bertahan pada status quo tanpa perubahan, akan tetapi jika diteliti lebih lanjut maka arah perkembangan masyarakat dan Negara modern akan selalu bergerak ke tiga model tersebut. Dalam dunia sekarang tidak banyak turbulensi yang terjadi, globalisasi masih berjalan sehingga penyebaran model ideal masih akan terjadi sebagai bentuk terbaik sebuah pemerintahan. Ketiga konsep yang dianggap model ideal AP diatas menjadi arah AP sekarang dan di masa mendatang, sampai saat ini belum ada tandatanda terjadi perubahan drastis yang mampu menggantikan ketiganya,memang ada secara teori yang memunculkan pendapat misalkan kritik New Public Service kepada New Public Management akan tetapi bangunan teori NPS tidak sekuat NPM dan NPM sendiri sepertinya sudah sangat mengakar kuat di negara-negara maju, bahkan kini NPS dianggap menjadi pelengkap bagi New Public Governance terutama bagaimana bangunan teori politik tentang equity yang ada NPG banyak mengutip dari NPS sendiri. Selain itu juga ada pemikiran dalam tulisan Ali Farazmand mengenai sound of governance, akan tetapi juga hanya menjadi bagian lagi dari pendekatan NPM, 
terutama bangunan teori yang masih menggunakan governance sehingga tidak dianggap baru.

Untuk membentuk suatu paradigma baru memang tidak mudah, seperti apa yang telah dijelaskan oleh Thomas Kuhn sebagai pencipta konsep paradigma. Paradigma baru harus berbeda dan lepas dari pandangan sebelumnya, terutama bagaimanacaramemandang masalah dan berbagai kompleksitas masalahnya. Jadi benar apabila paradigma baru harus mampu mengatasi masalah yang tidak dapat diatasi dengan cara lain dan menjadi bagian besar dari cara mengatasi masalah yang ada. Tentu jika kita melihat dunia sekarang maka masalah masih dianggap relevan bagi paradigma yang ada, paradigma masih. Berbagai paradigma hanya sebagai bagian dari cara untuk menyerdehanakan kompeksitas masalah tanpa mengurangi kadar pemaknaan, sama seperti ilmu lain dan tepatnya AP tetap masih bagian dari ilmu sosial. Instead, as most would agree, public administration is a branch of the social sciences (Riccucci, 2010).

\section{Administrasi Publik Untuk Reformasi}

Muncul titik temu untuk merangkai seluruh tahapan trajektori mulai dari administrasi publik klasik sebagai status quo, refokus ke arah politik dan manajemen, dan arah administrasi publik yaitu bahwa semua menuju arah perbaikan tata kelola pemerintahan. Dalam terminologi perbaikan tersebut dapat dikonsepkan sebagi reformasi, fungsi reform bagi pemerintah adalah jelas untuk merekonstruksi pemerintah semakin responsif, responsibel dan respected (Bourgon, 2007).

Secara sederhana AP dapat menjadi tools untuk melakukan perubahan dalam konsep reformasi administrasi, reformasi birokrasi, serta reformasi administrasi publik (Nemec, 2014; Pollit \& Bouckaert, 2011; Samaratunge, Alam, \& Teicher, 2008). Seperti inovasi kebijakan dan pelayanan publik (Pratama, 2013, 2018b, 2018a), perencanaan dan capacity building (Andrews, Pritchett, \& Woolccok, 2017), modifikasi perilaku aparatur dan masyarakat (Grimmelikhujsen, Jilke, Olsen, \& Tummers, 2016; John et al., 2011), adopsi teknologi informasi (Meijer \& Bolivar, 2016; Mergel, Edelmann, \& Haug, 2019) serta kolaborasi dan partisipasi masyarakat antar sektor (Nabatchi, Sancion, \& Sicillia, 2017). Oleh karena itu ke depannya tiga elemen penting akan selalu mewarnai dalam studi AP baik secara teoritik maupun praktik yaitu: Pertama, adopsi teknik dan metode dari sektor bisnis. Hal tersebut akan selalu menjadi solusi fasttrack dalam melakukan reformasi sektor publik untuk efisiensi dan efektivitas yang biasanya sudah terlebih dahulu ada di sektor binis. Kedua, penggunaan teknologi informasi yang masif. Elemen ini menjadi trend global di sektor manapun, oleh karena itu sektor bisnis maupun publik pasti akan mengikutinya. Ketiga, keterlibatan antar sektor. Kolaborasi dan partisipasi berbeda insitusi bukan hal yang tidak mungkin hari ini, semua sektor telah dibuka untuk terlibat dalam tugas-tugas pemerintahan untuk meningkatkan derajat keberhasilan kebijakan publik.

\section{KESIMPULAN}

Politik dan manajemen memberikan pengaruh besar terhadap perkembangan dan perubahan studi AP, bahkan diperkirakan ketika terjadi perubahan radikal politik dunia maka studi AP aka juga turut bergeser, serta manajemen yang diimpor langsung dari sektor swasta juga masih akan menjadi bagian dari adopsi teori-teori AP yang akan selalu mencari teori terbaik dalam kinerja organisasi ataupun bagian yang lainnya, bahkan idiom sebagus apapun kinerja sektor publik pasti akan selalu lebih outstanding kinerja milik sektor 
swasta. Tentu hal ini harus dipahami hanya sebatas kinerja bukan peredebatan masalah yang lain.

Perjalanan studi AP telah menemukan jalannya sendiri sebagai ilmu yang harus dimaknai sebagai ilmu yang tidak dapat berdiri sendiri akan tetapi memiliki karakter sendiri dan menjadi ciri khasnya terutama bagaimana memandang urusan sektor publik atau segala sesuatu yang berhubungan dengan publik secara umum. Ilmu AP bukanlah ilmu yang tidak jelas batasannya atau memiliki kadar kekaburan yang tinggi. Sepanjang kritik yang ada menunjukkan dinamika yang justru memperkarya studi AP bukan malah mematikan studi AP sendiri. Pola perjalanan AP dari masa lalu hingga masa depan dapat dikonsepkan menjadi sebuah trajektori AP. Trajektori ini tentu tidak dapat dianggap penuh dan berlaku mutlak tentu masih banyak kelemahan serta sangat perlu untuk dikritisi. Perkembangan dan perubahan studi AP telah mencapai tahap yang menggembirakan ketika pada era saat ini studi AP telah dianggap sebagai alat untuk mencapai kehidupan masyarakat dan Negara yang lebih baik, jika pemerintahan dianggap buruk maka AP dijadikan panduan untuk mereformasi sekaligus digunakan untuk meninjau kondisi pemerintahan saat ini melalui berbagai macam teori AP yang telah ada. Studi AP harus menjadi titik awal dalam memahami perubahan publik terutama dalam kehidupan bernegara dan kemudian untuk memperbaikinya maka dapat menggunakan berbagai analisis dari ilmu lain sehingga pemahaman lebih komprehensif serta tidak bersifat tunggal apalagi bersifat universal. Di dunia ini hampir tidak ada resep tunggal untuk menyelesaikan masalah, disinilah keunggulan studi AP terletak dan seharusnya menjadi kunci perkembangan studi di masa mendatang.

\section{DAFTAR RUJUKAN}

Andrews, M., Pritchett, L., \& Woolccok, M. (2017). Building State Capability: Evidence, Analysis, Action. Oxford: Oxford University Press.

Bourgon, J. (2007). Responsive, Responsible and Respected Government: Towards a New Public Administration Theory. International Review of Administrative Sciences, 73(1), 7-26. https://doi.org/10.1177/0020852307075686

Bozeman, B. (2007). Public Values and Public Interest: Counterbalancing Economic Individualism. Washington, D.C: Georgetown University Press.

Denhardt, J. V., \& Denhardt, R. B. (2007). The New Public Service: Serving, Not Steering. New York: M.E. Sharpe.

Drechsler, W. (2005). The Rise and Demise of The New Public Management. Post-Autistic Economic Review, 33.

Drechsler, W. (2015). Paradigms of non-western PA and governance. In A. Massey \& K. J. Miller (Eds.), The international handbook of public administration and governance (pp. 104-131). Cheltenham: Elgar.

Drechsler, W. (2017). Islamic public administration in Europe. In E. Ongaro \& S. van Thiel (Eds.), The Palgrave Handbook of Public Administration and Management in Europe (pp. 1031-1047). https://doi.org/10.1057/978-1-137-55269-3_52

Drechsler, W., \& Kattel, R. (2008). Towards the Neo Weberian State? Perhaps, but Certainly, adieu, NPM!. The NISPAcee Journal of Public Administration and Policy, (Special Issue).

Dwiyanto, A. (2004). Reorientasi Ilmu Administrasi Publik : Dari Government Ke Governance. Yogyakarta.

Emerson, K., Nabatchi, T., \& Balogh, S. (2011). An Integrative Framework for Collaborative Governance. Journal of Public Administration Research and Theory, 22(1), 1-29.

Farazmand, A. (2004). Sound Governance: Policy and Administrative Innovations. London: 
Praeger.

Farazmand, A. (2012). The Future of Public Administration: Challenges and Opportunities --A Critical Perspective. Administration \& Society, 44(4), 487-517. https://doi.org/10.1177/0095399712452658

Frederickson, G. H. (1980). New Public Administration (Second). Alabama: Alabama University Press.

Grimmelikhujsen, S., Jilke, S., Olsen, A. L., \& Tummers, L. (2016). Behavioral Public Administration: Combining insight from Public Administration and Pscychology. Public Administration Review, 77(1).

Henry, N. (2012). Public Administration and Public Affairs. In Public Administration and Public Affairs (12th ed.). https://doi.org/10.4324/9781315663067

John, P., Cotterill, S., Moseley, A., Richardson, L., Smith, G., Stoker, G., \& Wales, C. (2011). Nudge, Nudge, Think, Think: Experimenting with Ways to Change Civic Behaviour. New York: Bloomsbury.

Mantra, D. (2015). Perkembangan dan Permasalahan Teorisasi Hubungan Internasional Pasca Perdebatan. Hubungan Internasional, 4(2), 105-117.

Meijer, A., \& Bolivar, M. P. R. (2016). Governing Smart City. International Review of Administrative Sciences, 82(2), 392-408.

Mergel, I., Edelmann, N., \& Haug, N. (2019). Defining digital transformation: Results from expert interviews. Government Information Quarterly, 36(4).

Nabatchi, T., Sancion, A., \& Sicillia, M. (2017). Varieties of Participation in Public Service: The Who, When, and What of Coproduction. Public Administration Review.

Nemec, J. (2014). Comparative Analysis of Public Administrations Reform in Former Socialist Countries of Central and Eastern Europe. International Journal of Civil Service Reform \& Practice, 4(4), 93-113.

Osborne, D., \& Gaebler, T. (1993). Reinventing Government: How the Entrepreneurial Spirit is Transforming the Public Sector. New York: Plume.

Osborne, S. P. (2010). The New Public Governance: Emerging Perspective on Theory and Practice of Public Governance (S. P. Osborne, ed.). London: Routledge.

Pesch, U. (2008). The Publicness Of Public Administration. Administration \& Society, 40(2).

Pollit, C., \& Bouckaert, G. (2011). Public Management Reform: A Comparative Analysis New Public Management, Governance, and The Neo Weberian State. Oxford: Oxford University Press.

Pollit, C., \& Bouckaert, G. (2017). Public Management Reform: A Comparative Analysis into the Age of Austerity. Oxford: Oxford University Press.

Pratama, M. R. (2013). Inovasi Pelayanan Publik ( Studi Deskriptif Tentang Nilai Tambah ( Value Added ) Inovasi Pelayanan Perizinan Bagi Masyarakat Di Kota Kediri ). Manajemen Dan Kebijakan Publik, 1(2), 218-225.

Pratama, M. R. (2018a). Innovation Process in Public Service : Studying Innovation Process in Yogyakarta City Licensing Service Clinic Unit ( KLIPPER ). Studi Pemerintahan, 9(2), 250-268.

Pratama, M. R. (2018b). Proyeksi Fundamen Pelayanan Publik Menuju Pelayanan Publik Ideal. Jurnal Ilmu Administrasi, XV(1), 88-96.

Raadschelders, J. C. N., \& Lee, K. H. (2011). Trends in the Study of Public Administration: Empirical and Qualitative Observations from Public Administration Review, 20002009. Public Administration Review, 71(1), 19-33. https://doi.org/10.1111/j.15406210.2010.02303.x

Rhodes, R. (1996). The New Governance: Governing without Government. Political Studies, $44,652-667$. 
Riccucci, N. M. (2010). Public Administration: Traditions of Inquiry and Philosophies Knowledge. New York: Georgetown University Press.

Rosenbloom, D. H. (2013). Reflection On Public Administrative Theory And Separation Of Power. American Review of Public Administration, 43(4).

Samaratunge, R., Alam, Q., \& Teicher, J. (2008). The new public management reforms in Asia: A comparison of South and Southeast Asian countries. International Review of Administrative Sciences, $74(1), \quad 25-46$. https://doi.org/10.1177/0020852307085732

Snyder, H. (2019). Literature review as a research methodology: An overview and guidelines. Journal of Business Research, 104(August), 333-339. https://doi.org/10.1016/j.jbusres.2019.07.039

Stivers, C. (2001). Democracy, Bureaucracy and The Study of Administration. Colorado: Westview Press.

Stoker, G. (2006). Public Value Management: A New Narrative for Networked Governance. American Review of Public Administration, 36(1).

Susanto, J. (2012). Menuju Trajektori Baru: Sebuah Manifesto untuk Studi Hubungan Internasional Indonesia. Global \& Strategis, 6(2), 135-169.

Templier, M., \& Pare, G. (2016). A Framework for Guiding and Evaluating Literature Reviews. Communications of the Association for Information Systems, 37(6). https://doi.org/10.17705/1CAIS.03706

Tomor, Z., Meijer, A., Michels, A., \& Geertman, S. (2019). Smart Governance For Sustainable Cities: Findings from a Systematic Literature Review. Journal of Urban Technology, 3-27.

Vigoda, E. (2002). Public Administration: An Interdiscplinary Critical Analysis. New York: Marcel Dekker, Inc.

Wilson, W. (1887). The Study of Administration. Political Science Quartely, 2(2). 